\title{
THE VASA EFFERENTIA IN THE RAT AND MOUSE
}

\author{
E. R. A. GOOPER AND H. JAGKSON \\ Unit of Reproductive Pharmacology, University of Manchester, \\ Manchester M13 9PL
}

(Received 17th September 1971, accepted 20th September 1971)

According to Wakeley (1943-44), the majority of epididymal cysts in man arise in the vasa efferentia, the bridge of tissue between the testis and epididymis. The ability of two sterilant chemicals to produce specific lesions of this nature in the rat $(\alpha$-chlorhydrin-Ericsson, 1970; ethylenedimethanesulphonate-Cooper \& Jackson, 1970) points to the need for further information on the vasa efferentia in relation to their susceptibility to damage in this manner. As there appears to be inadequate information on the course of these tubules, the present study was undertaken.

At post mortem, the testes resting in the scrotum of the rat present anterior and posterior surfaces and medial and lateral rounded borders. Serial longitudinal sections were made in both rat and mouse of the entire testis-epididymisvas complex, from the anterior to the posterior surface. In sections from a number of rats, it was observed that the rete testis penetrates into the tunica albuginea and from it, two channels of vasa efferentia emerge (Pl. 1, Fig. 1); the arrangement is similar in the mouse (Pl. 1, Fig. 4). In the rat, both tubules become convoluted in relation to a non-tortuous artery and vein, which are branches of the superior epididymal vessels. The two channels and the blood vessels ascend in a column of fat covered by a peritoneal layer, inclining slightly laterally and posteriorly. In its ascent, each passes behind the caput epididymidis to a variable distance above it. There, the tubules arch medially and anteriorly (the arch, PI. 1, Figs. 2 and 3 ) and gain the upper margin of the proximal caput into which the vasa efferentia become incorporated (Pl. 1, Fig. $3)$. It is at the arch that the nutrient vessels join the tubules from the lateral aspect. The vasa efferentia are relatively large at their origin from the rete testis (P1. 2, Figs. 5 and 6) and become smaller as they approach their union with the caput. A single layer of cubical to columnar epithelium supported by delicate fibres forms the wall, while stroma envelops them. Invariably, the vasa are empty in sections of normal specimens.

According to Cunningham (1928), the vasa efferentia of the rat leave the testis, pass dorsal to the epididymis and join the anterior lobe of the caput. Harrison (1953) and Macmillan (1953), in their drawings from the rat, show the vasa entering the inferior aspect of the proximal caput epididymidis. Reid \& Cleland (1957) found that the efferent ducts pass superiorly and dorsally as individual ducts, eventually joining a common terminal duct which extends from the dorso-medial surface of the caput. This, and Cunningham's account are more consistent with the present findings. Opinions vary as to the number of 
vasa efferentia in the rat: for example, twelve to twenty (Van Wagenen, 1924; Marshall, 1960), six (Macmillan, 1953, as shown in his text figures) and five (Reid, 1959). The vasa are said to unite into a single channel which joins the caput epididymidis (Macmillan, 1953; Reid \& Cleland, 1957).

In the present study of longitudinal rather than transverse serial sections of the testis-epididymis complex in both rat and mouse, only two efferent channels were recognized at their origin from the rete testis. Each appeared to remain independent along its tortuous course (PI. 2, Fig. 6), becoming smaller and losing its individuality on entering the proximal caput epididymidis. This suggests that the two channels become the common terminal duct as noted by Reid \& Cleland (1957). From the serial sections under discussion, it appears that this terminal duct actually comprises the proximal lobule of the caput (Pl. 1, Fig. 3).

Following an injection of ethylenedimethanesulphonate $(75 \mathrm{mg} / \mathrm{kg}$ intraperitoneally), sections showed that in some instances a portion of one channel only was affected (Pl. 1, Fig. 2; Pl. 2, Figs. 5 and 6 ) and occasionally both were involved. In the early stages, the lining epithelium was hyperplastic, and small intratubular retention cysts (spermatocoeles) had arisen where spermatozoa were arrested. Later, the small formations coalesced and some cellular reaction in the stroma was apparent. By contrast, both vasa efferentia were always involved after a large dose of $\alpha$-chlorhydrin $(120 \mathrm{mg} / \mathrm{kg}$ orally) and characteristic intratubular spermatocoeles were invariably formed (Pl. 2, Fig. 7). Those near the origin of the vasa efferentia were larger than the more distal ones (Pl. 2, Fig. 8) and the walls of the former were attentuated and fragmented. Stromal cells had reacted to the escape of spermatozoa and sperm granulomata resulted (Pl. 2, Fig. 8). On occasions, these reached a large size but showed no sign of resolution with time, hyalinization and fibrosis supervening. In the mouse, neither ethylenedimethanesulphonate nor $\alpha$-chlorhydrin produced lesions in the post-testicular pathway.

Other evidence supports a two-channel hypothesis for the vasa efferentia of the rat. In one rat explored 17 days after the dose of ethylenedimethanesulphonate, a characteristic epididymal spermatocoele at the corpus-cauda junction was present on the right side. As no lesions were observed on the left

\section{EXPLANATION OF PLATES}

Nos. 1 and $2=$ Two channels of vasa efferentia. No. $3=$ Rete testis. Nos. 4,5 and $6=$ Origin, ascent, and arch of vasa efferentia. No. $7=$ Junction of vasa efferentia with proximal caput epididymidis (8). Nos. 8 and $9=$ Proximal and middle caput epididymidis. No. $10=$ Blood vessel $(\mathrm{s}) . \mathrm{B}=$ Blocked vasa efferentia. $\mathrm{SC}=$ Spermatocoele. $\mathrm{SG}=$ Sperm granuloma .

\section{PLATE 1}

FIG. 1. Normal rat. Two channels of vasa efferentia arise from the rete testis. $\times 30$. Fig. 2. Rat, 100 days after $75 \mathrm{mg}$ ethylenedimethanesulphonate (EDS) $/ \mathrm{kg}$. Two channels of vasa efferentia. A block is present in a portion of channel 1 . The majority of the testis tubules have not recovered. $\times 30$.

FIG. 3. Rat, 91 days after $75 \mathrm{mg}$ EDS/kg. The origin, ascent, arch and junctional portion of the vasa efferentia are seen almost in their entirety. There are no lesions in the vasa efferentia, spermatogenesis has recovered and the caput epididymidis is filled with spermatozoa. $\times 30$.

FIg. 4. Two channels of vasa efferentia in a mouse. $\times 90$. 
PLATE 1

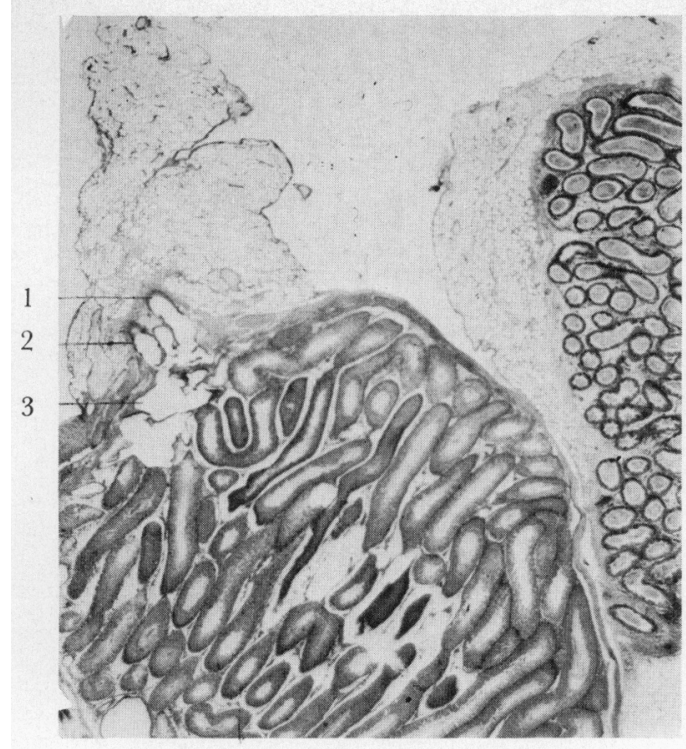

FIG. 1.

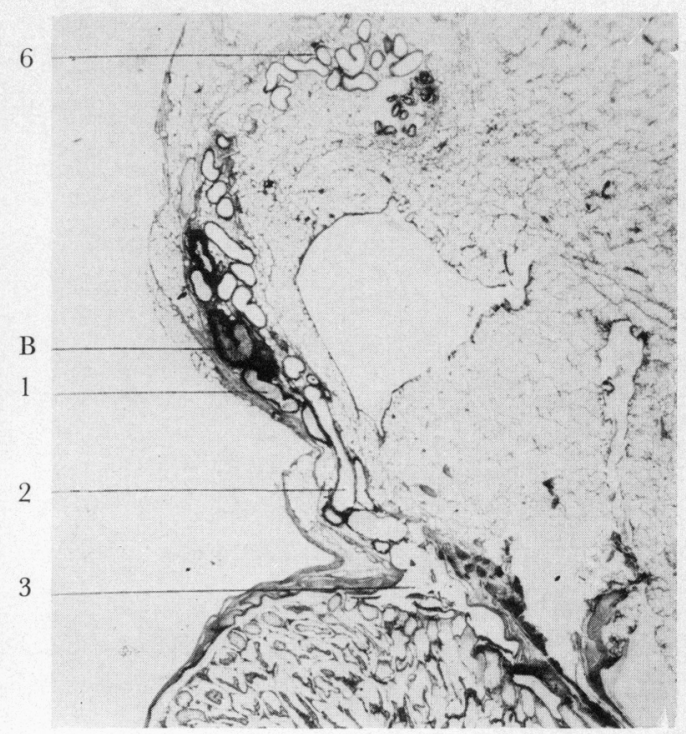

FIG. 2.

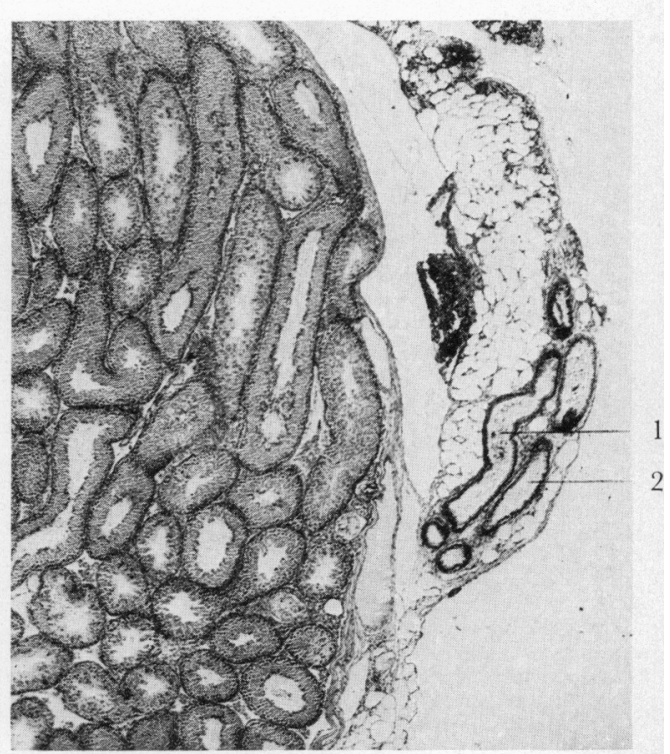

Fig. 4. 
PLATE 2

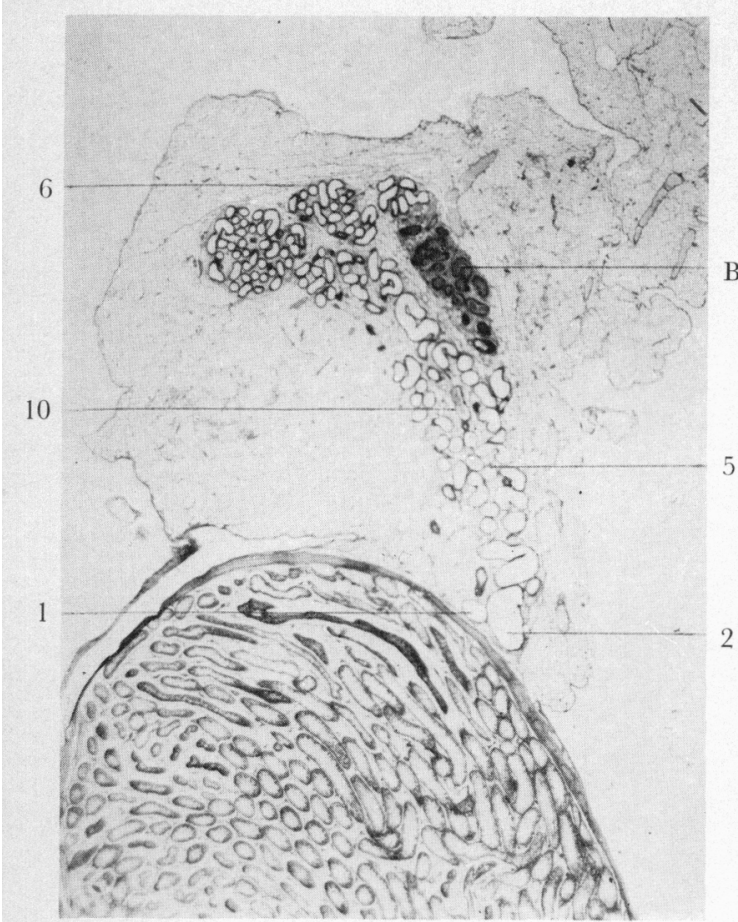

FIG. 5.

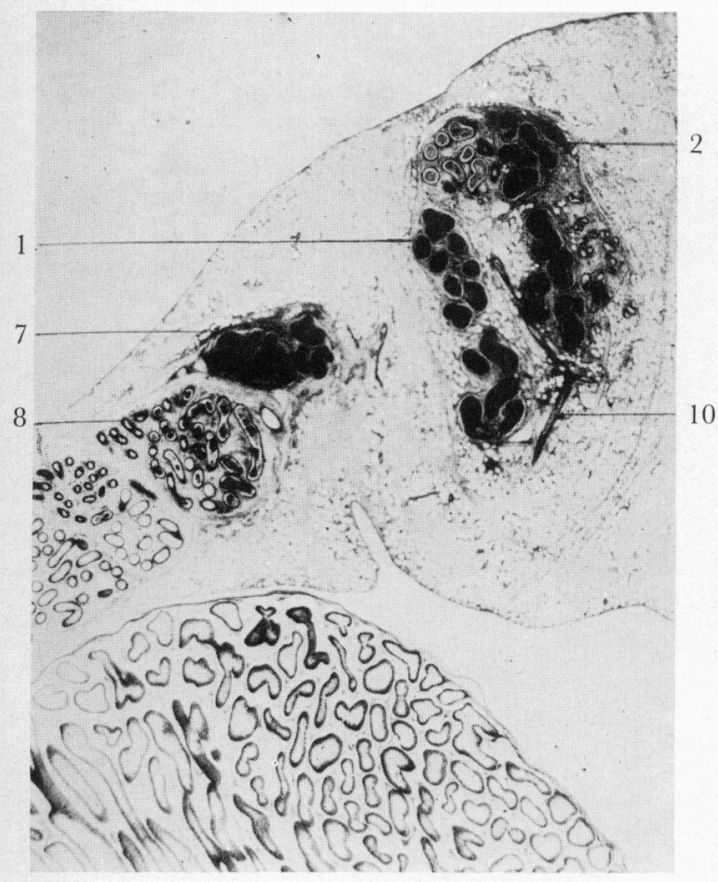

FIG. 7.

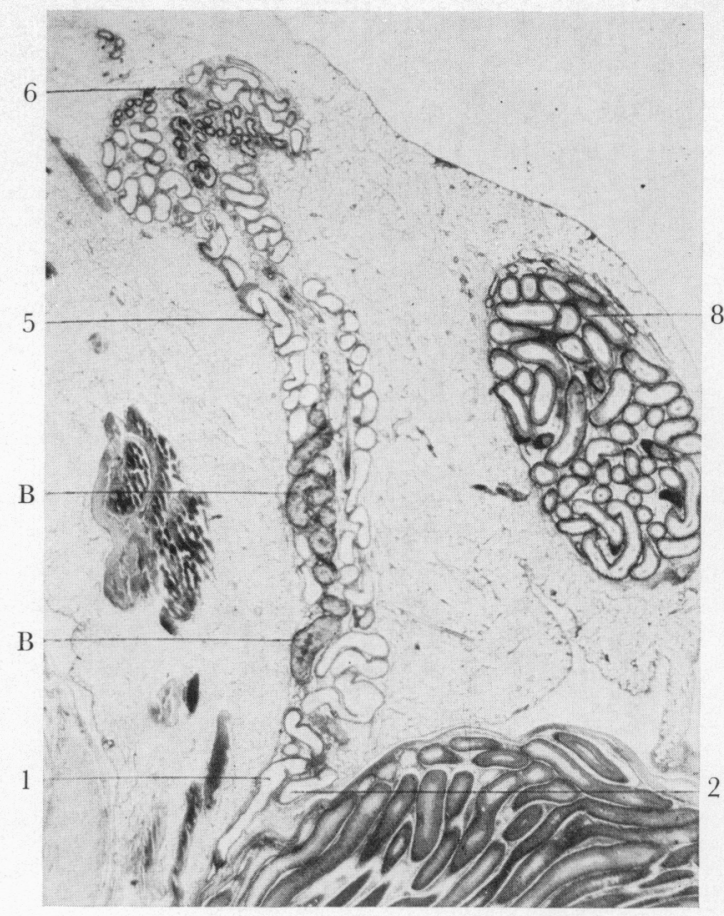

FIG. 6.

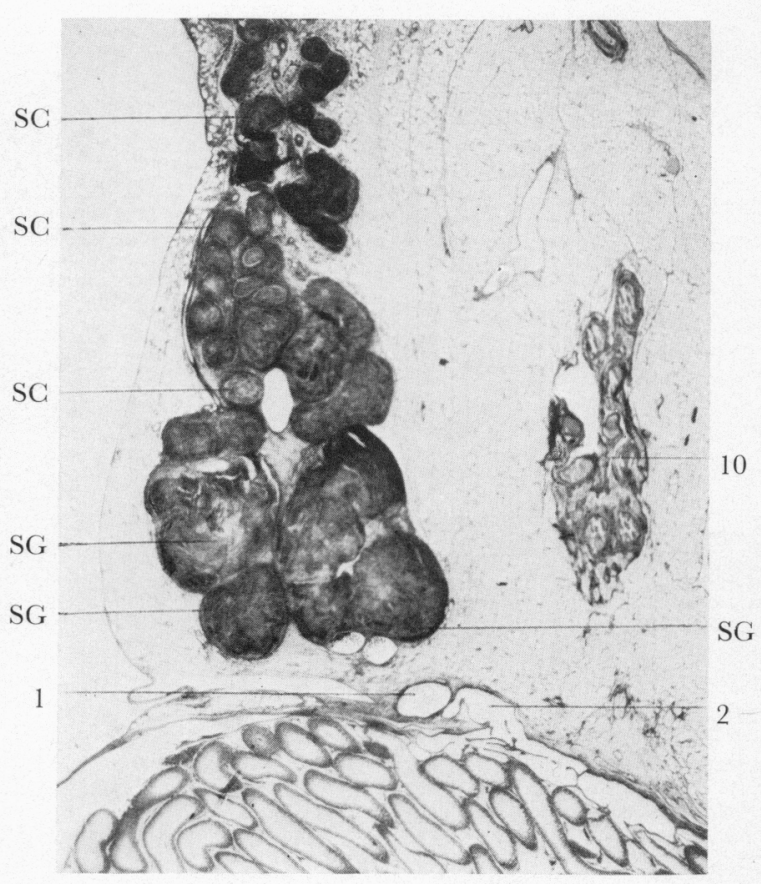

FIG. 8. 
side, the testis and epididymis were removed. Later, after spermatogenesis had recovered (Cooper \& Jackson, 1970), the rat was mated and a normal litter of twelve resulted. Sections of the remaining testis and epididymis showed that the observed spermatocoele at the corpus-cauda junction had almost completely resolved and was canalized. However, a block affecting a portion of one efferent channel was unresolved (Pl. 2, Fig. 6) but the other was patent and must have served as the pathway for passage of the spermatozoa. By contrast, $\alpha$-chlorhydrin caused irreparable damage to both channels of the vasa efferentia, followed by progressive loss of spermatogenic function.

This work was carried out with the support of grants from the Ford Foundation and Schering Chemicals Ltd.

\section{REFERENCES}

COOPER, E. R. A. \& Jackson, H. (1970) Comparative effects of methylene, ethylene and propylene dimethanesulphonates on the male rat reproductive system. 7. Reprod. Fert. 23, 103.

Cunningham, J. T. (1928) On ligature of the vas deferens in the cat, and researches on the efferent ducts of the testis in cat, rat and mouse. F. exp. Biol. 6, 12.

ERICsson, R.J. (1970) Male antifertility compounds. U-5897 as a rat chemosterilant. F. Reprod. Fert. 22, 213.

Harrison, R. G. (1953) The effect of ligation of the vasa efferentia on the rat testis. Proc. Soc. Study Fert. $5,97$.

Macmillan, E. W. (1953) Higher epididymal obstructions in male infertility. Fert. Steril. 4, 101.

Marshall's Physiology of Reproduction (1960) Ed. A. S. Parkes, 3rd edn, vol. 1, 94. Longmans, London.

REID, B. L. (1959) The structure and function of the epididymis. II. The histogenesis of the rat epididymis. Aust. 7. Zool. 7, 22.

Reid, B. L. \& Cleland, K. W. (1957) The structure and function of the epididymis. I. The histology of the rat epididymis. Aust. F. Zool. 5, 223.

VAn Wagenen, G. (1924) Degeneration of the germinal epithelium in the testis of the rat as a result of efferent duct ligation. (Abstract). Anat. Rec. 27, 189.

WAKELEY, C.P.G. (1943-44) Cysts of the epididymis, the so-called spermatoceles. Br. F. Surg. 31, 165.

\section{PLATE 2}

Fig. 5. Rat, 12 days after $75 \mathrm{mg}$ EDS/kg. A block is present in a portion of one efferent channel. Depletion of seminiferous epithelium. $\times 30$.

Fig. 6. Rat, 119 days after $75 \mathrm{mg}$ EDS/kg. The testis, vasa efferentia and caput epididymidis An unresolved block is present in part of one efferent channel, but the testis has fully recovered. $\times 30$.

Fig. 7. Rat, 4 days after $120 \mathrm{mg} \alpha$-chlorhydrin $/ \mathrm{kg}$. Both channels of the vasa efferentia are blocked. $\times 30$.

FIG. 8. Rat, 9 days after $120 \mathrm{mg} \alpha$-chlorhydrin $/ \mathrm{kg}$. Both channels of the vasa efferentia are blocked. Near the origin are large sperm granulomata; further away, smaller spermatocoeles are present. $\times 30$. 